○

OPEN ACCESS

EDITADO POR

- Valéria Severina Gomes

(UFRPE)

- Aurea Zavam (UFC)

- Konstanze Jungbluth

(EUV)

AVALIADO POR

- Renata Ferreira Costa

Bonifácio (UFS)

- Camila de Lira Santos

(Linguarte e.V.)

SOBRE OS AUTORES

- Natanael Duarte de Azevedo Conceptualização, Curadoria de dados, Investigação,

Metodologia, Análise formal e Escrita - análise e edição.

- José Temístocles Ferreira Jr. Curadoria de dados, Análise formal e Escrita - análise e edição.

DATAS

- Recebido: 30/10/2020

- Aceito: 27/11/2020

- Publicado: 17/12/2020

COMO CITAR

Azevedo, N. D.; Ferriera Jr., J. T. (2020). Historicidade das cartas de amor: circulação de manuais epistolares portugueses no Brasil do século XIX. Revista da Abralin, v. 19, n. 3 , p. 628-653, 2020.
ENSAIO TEÓRICO

\section{Historicidade das cartas de amor: circulação de manuais epistolares portugueses no Brasil do século XIX}

\author{
Natanael Duarte de AZEVEDO (D) \\ Universidade Federal Rural de Pernambuco (UFRPE)
}

José Temístocles FERREIRA JÚNIOR (D)

Universidade Federal Rural de Pernambuco (UFRPE)

RESUMO

O presente ensaio sobre a historicidade das cartas de amor portuguesas busca compreender a composição do gênero carta pessoal de amor a partir de sua circulação no Brasil durante o grande século XIX: Secretario Portuguez, ou methodo de escrever cartas (1786), de Francisco José Freire; Mensageiro dos Amantes: Carcaz de Fréchas Amatorias; Manual Epistolar Galante (18--), de Damião Casamenteiro; Secretario Completo dos Amantes (19--), Imp. Lucas \& $C^{\text {a }}$. Com essa investigação, podemos apresentar algumas contribuições para a História da Leitura e da Literatura, ancoradas no paradigma teórico das Tradições Discursivas, no que diz respeito ao gênero textual como objeto de pesquisa. Dada a natureza do trabalho, assumimos duas frentes do referencial teórico: para compreensão da carta de amor como gênero literário, nos apoiamos em Romero (1888), Barbosa (2011; 2012) e Castillo Gómez (2002); para os estudos diacrônicos do gênero, tomamos Kabatek (2005; 2012), Gomes (2007) e Zavam (2009). Com esse ensaio, identificamos que marcas composicionais da carta de amor se mantêm ao longo do recorte temporal, mesmo que haja mudanças significativas de ordens tipográficas, temáticas e de apropriação do sentido do amor. 


\section{REVISTA DA ABRALIN}

\section{ABSTRACT}

The present essay on the historicity of Portuguese love letters aims to understand the composition of the genre personal love letter during its circulation in Brazil in the nineteenth century: Secretario Portuguez, ou methodo de escrever cartas (1786), by Francisco José Freire; Mensageiro dos Amantes: Carcaz de Fréchas Amatorias; Manual Epistolar Galante (18-), by Damião Casamenteiro; Secretario Completo dos Amantes (19--), Imp. Lucas \& $\mathrm{C}^{\text {a }}$. With this investigation, we intend to present some contributions to the History of Reading and Literature, anchored in the theoretical paradigm of Discursive Traditions, regarding the textual genre as an object of study. Given the nature of the work, we assume two fronts of the theoretical framework: in order to understand the love letter as a literary genre, our research is based on the studies of Romero (1888), Barbosa (2011; 2012) and Castillo Gómez (2002); for diachronic studies of the genre, we take Kabatek (2005; 2012), Gomes (2007) and Zavam (2009). We identified that compositional marks of love letters remain throughout the time even if there are significant changes in typographic, thematic orders and appropriation of the meaning of love.

\section{PALAVRAS-CHAVE}

Cartas de amor. Tradição Discursiva. História da Leitura e da Literatura. Análise de gêneros escritos.

\section{KEYWORDS}

Love letters. Discursive traditions. History of Reading and Literature. Analysis of written genres.

\section{Introdução}

A produção epistolar circulou durante séculos no cenário das Belas Letras, sendo sua presença evidenciada nos séculos XVII, XVIII e XIX, na França, na Inglaterra, na Espanha, em Portugal, até chegar no Brasil, em oitocentos. Vale destacar que na Espanha, por exemplo, a circulação de manuais epistolares em meados do século XVI e início do XVII era considerada um sucesso através de edições e reedições, promovendo uma determinada política de escritura (CASTILLO GÓMEZ, 2002). 


\section{REVISTA DA ABRALIN}

A cultura da escrita de missivas no grande século XIX ${ }^{1}$ tinha grande circulação nos suportes livro e jornal, tendo neste último, por seu caráter heteróclito e multifacetado, um porto de ancoragem para o gênero epistolar e, justamente por sua recorrente presença no impresso, tornou-se "um dos gêneros fundadores da escrita em jornais e periódicos" (BARBOSA, 2012, p. 332). Por essa razão, o gênero carta foi tomado como objeto de investigação em pesquisas desenvolvidas no campo da Historiografia da Literatura.

O caráter histórico e as particularidades observáveis em sua escrita fazem do gênero carta um bem simbólico e, ainda assim, é um tema pouco explorado no campo da literatura. Naturalmente, tomar o gênero carta como objeto de investigação em um campo que não o considera como integrante do cânone demanda implicações de ordem teórico-metodológicas e epistemológicas para o investigador. Nesse aspecto, cabe ressaltar algumas observações feitas por Chartier (1991, p. 178), que destaca a organização do seu trabalho na história da literatura em torno de três polos: a) o estudo crítico dos textos, literários ou não, canônicos ou esquecidos; b) a história dos livros e de todos os objetos que contêm a comunicação do escrito; c) a análise das práticas que se apreendem dos bens simbólicos, produzindo, assim, usos e significações diferenciadas.

Por outro lado, no campo da Linguística, alguns trabalhos ganham corpo no Brasil, a partir da década de 1990, através do paradigma das Tradições Discursivas (doravante TD), levando em consideração a análise por meio de conceitos variados, que vão dos aspectos linguístico-discursivos ao arcabouço epistemológico dos estudos diacrônicos do texto (CARVALHO; ZAVAM, 2018).

Em relação às TD, o foco de nossa análise será a partir dos estudos diacrônicos do texto e não entraremos nas discussões que tomam as TD como sinonímia, ou, novo modo de dizer, de gêneros textuais.

Em diferentes trabalhos, ambos os termos são equiparados a tal ponto, que, às vezes, parece que a tradição dos estudos de gênero é renovada com um termo novo em aparente inovação que, na realidade, não é mais do que vinho velho em odres novos. (KABATEK, 2012, p. 580).

Nesse sentido, nosso estudo busca compreender como as cartas de amor, enquanto gênero textual que circulou nos manuais epistolares portugueses, no território brasileiro de oitocentos, podem ser analisadas a partir de pressupostos metodológicos emprestados das TD, mas não como uma pura tradição discursiva. Dessa forma, como bem pontuou Kabatek (2012, p. 587), "todos os gêneros são tradições discursivas, mas nem todas as tradições discursivas são gêneros".

Interessa-nos para análise, em especial, o gênero carta pessoal de amor, uma vez que, ao reconhecer a pluralidade temática da carta, é necessário estabelecer um recorte para construção de nosso corpus, composto por 14 cartas de amor. Vale destacar que quando analisamos as cartas de amor é preciso perceber as recorrências de expressões que buscam construir a representação de sentimentos ternos. Por meio da temática amorosa, esses manuais epistolares ganharam destaque de divulgação nas livrarias e nos jornais brasileiros de oitocentos, principalmente após as décadas de 1880 e 1890 (EL FAR, 2004). Uma possível razão é a sua multiplicidade de temas e o seu caráter

\footnotetext{
${ }^{1}$ Também chamado "longo século XIX", compreende o período de 1776 a 1914 (HOBSBAWM, 1988).
} 


\section{REVISTA DA ABRALIN}

intimista, fazendo com que a carta de amor ganhasse destaque no cenário literário amoroso e voyeurístico das Belas Letras finisseculares (LAJOLO, 2002).

A escolha por esse gênero carta se deu pela grande circulação que ele teve no Brasil do século XIX (EL FAR, 2004), e também pela possibilidade de apreendermos a representação que ele traz do amor, uma vez que as cartas de amor são modelos da literatura cortês - da arte de cortejar o amor da mulher pretendida.

É importante compreender, que a priori, o gênero epistolar não era visto como uma das representações da literatura no século XIX, e isso se dava porque a erudição e os modelos importados da Europa moldavam o padrão brasileiro conceitual de literatura: "[...] até o fim do século XIX o que parece ser Literatura são textos que mantêm certo caráter didático, aquele antigo, que englobava a eloquência, a poesia, a história, a crítica e também as ciências" (BARBOSA, 2005, p. 6).

Logo, assim como as epístolas de modo geral, as cartas de amor não continham as características necessárias para serem consideradas representantes da arte do escrever. Nesse sentido, as cartas que possuíam em sua mais intensa forma uma composição amorosa e subjetiva se eximiam das obrigatoriedades de ter de referenciar a poesia, a história ou a ciência. O conteúdo primordial encontrado nas cartas de amor no século XIX era o sentimento amoroso e todas as intempéries e infortúnios, aos quais o indivíduo poderia subjugar-se.

A arte de escrever cartas também mantém uma estreita relação com a materialidade do suporte em que circulavam. Esse olhar cuidadoso para o suporte se deve ao fato de que ele pode influenciar, determinando e/ou modificando, em alguns casos, os gêneros e os modos de ler (CHARTIER, 1998), incidindo na produção de sentido e nos modos de interpretação em uma dada época. Assim, não basta ao texto literário existir, pois ele é materializado pelo sentido empreendido pelo sujeito leitor; é preciso considerar sua relação com o suporte em que circula. Em outros termos, a apropriação do livro pelo leitor será responsável por toda representação de sentido da obra e da sociedade na qual ela foi lida.

É no jogo fronteiriço entre a representação do amor e as marcas composicionais da carta de amor que propomos uma investigação que contribua tanto para os estudos da História da Leitura e da Literatura como das Tradições Discursivas, uma vez que buscamos compreender a composição do gênero carta pessoal de amor, através dos manuais epistolares, bem como identificar se há ou não mudanças significativas de ordens tipográficas, temáticas e de apropriação do sentido do amor numa perspectiva diacrônica, pois é no questionamento sobre o sujeito leitor e suas práticas de leitura que entendemos a necessidade de uma contextualização física, espacial e temporal para poder fazer significar um determinado texto. 


\section{Dos manuais epistolares e das cartas de amor: composição e conceitos}

De forma recorrente, o conteúdo temático das cartas de amor no grande século XIX se voltava para a mulher e, nesse sentido, a representação da mulher nas cartas de amor era feita por um viés estigmatizado do sentimento, visto que se observa nos manuais epistolares portugueses que circularam no Brasil oitocentista a figura da amada caracterizada no imaginário coletivo como pura, casta, frágil e inocente. Percebemos uma preocupação maior em descrever as formas que o amor possui, ou seja, os caminhos de validação do sentimento por parte do amante (embora também haja uma exaltação divinal ao sentimento). De fato, não há foco nos sintomas que acometem os apaixonados e sim nas intempéries que terão de ser superadas para que o indivíduo se mostre digno do amor, e esse comportamento equivale para ambos os sexos.

O amor permite que o sujeito faça qualquer coisa para manter a pessoa amada, mesmo que à custa de muito sofrimento. Nas cartas de amor, mostrar-se cavalheiresco e digno parece ser uma estratégia recorrente de representação dos sentimentos do homem para conquistar a mulher amada. Esse aspecto constitui uma apropriação da representação do amor cortês nas poesias medievais. Conforme C. S Lewis:

[...] o sentimento, é claro, é de amor, cujas características podem ser enumeradas como Humildade, Cortesia, Adultério e a religião do amor. O amante é sempre servil. O atendimento aos menores caprichos da donzela, por mais extravagantes, e a aquiescência silenciosa de suas censuras, por mais injustas, são as únicas virtudes que ele ousa reivindicar. (LEWIS, 2012 p. 14).

Nesse sentido, temos uma representação de amor como sacrifício em forma de concessão, pois o amante é capaz de submeter-se aos maiores atos de injustiças para ver a amada contente. É importante apontar que tanto em Lewis como em Ovídio as prerrogativas aparecem do ponto de vista masculino, mas nos Secretarios e manuais epistolares, as definições e padrões servem para ambos os sexos. Uma coisa é certa nos três conceitos propostos por Lewis (2012): amor é subserviência, e esse comportamento necessitará de empenho e renúncia da parte de quem ama.

Destacamos, entretanto, que é no século XVIII, na história da literatura, em um período de significativas mudanças de organização social, que as cartas de amor também apresentam uma outra configuração diferente do amor terno e casto. Os romances epistolares eróticos surgem com elevado destaque. Podemos citar alguns exemplos, como os romances epistolares libertinos da arte de amar e da arte de gozar: Teresa filósofa ou Memórias para servir à história do Padre Dirrag e da Senhorita Éradice (1748), de Jean-Baptiste de Boyer/Marquês d'Argens (França); Fanny Hill ou Memórias de uma mulher de prazer (1749), de John Cleland (Inglaterra); As relações perigosas (1782), de Choderlos de Laclos (França). Vale destacar que, como bem pontuou o crítico literário brasileiro Sílvio Romero, o século XVIII não foi "um grande século somente na Europa; elle o é também na America. É a phase da preparação das colônias para a vida livre, é o tempo das primeiras tentativas de libertação no continente" (ROMERO, 1888, p. 187). 


\section{REVISTA DA ABRALIN}

Nesse sentido, precisamos demarcar temporalmente e geograficamente os nossos objetos de análise: manuais epistolares portugueses que circularam no Brasil durante o longo século XIX. Os estudos desenvolvidos acerca das cartas necessitam de uma compreensão acerca da função social que esse gênero exerceu na sociedade luso-brasileira do século XIX, do lugar assumido por ele no mercado editorial, da caracterização física dos livros (secretários e manuais epistolares) que continham tais cartas e da representação que as missivas produzem acerca do amor.

Para tanto, iremos nos apoiar nas considerações de Alain Choppin (2002), no que tange à produção dos manuais como reveladores do perfil de uma sociedade e do caráter transformador que esses manuais exerceram nos leitores:

[...] os autores de manuais não pretendem somente descrever a sociedade, mas também transformála [...] Se um livro de classe é necessariamente redutor, as escolhas que são operadas por seus idealizadores tanto nos fatos como na sua apresentação (estrutura, paginação, tipografia, etc.) não são neutras, e os silêncios são também bem reveladores: existe dos manuais uma leitura em negativo! (CHOPPIN, 2002, p. 22)

Para além do lugar assumido pelos autores, editores e tipógrafos dos manuais epistolares, em relação ao papel instrutivo e transformador, é importante destacar que há na produção das cartas uma relação dual, dialógica, de um eu para um outro, uma vez que a missiva revela "uma estética da sedução, concebida tanto como busca de si como conquista do outro" (RIAUDEL, 2000, p. 95).

Barbosa (2011) vê que no caso da circulação desses manuais no território brasileiro em oitocentos, principalmente as obras oriundas de Portugal, há a hipótese de que a circulação e a popularidade desses livros no país se deram a partir da segunda metade do século XIX: "[os secretários e manuais] deixam de pertencer ao gênero dos manuais de civilidade, destinados à educação dos membros das classes abastadas, fato que garantia aos seus autores o status de 'agentes' deste processo e passam a constituir fórmulas gastas, 'utilíssimo a todas as classes'” (BARBOSA, 2011, p. 81).

\section{O Secretario Portuguez, o Mensageiro dos Amantes e o Secretario Completo dos Amantes: erudição e perfeições do secretário}

O Secretario Portuguez, ou methodo de escrever cartas (1786), de Francisco José Freire, é um manual que consiste na disseminação da prática epistolar, sendo composto por códigos regrados que orientavam a escrita de missivas. Nesse sentido, torna-se válido construir uma linha temporal sobre a produção epistolar, uma vez que é notável a refiguração dos Secretarios ao longo do tempo, bem como a necessidade do funcionamento de uma dada sociedade a partir das práticas epistolares.

A primeira edição do Secretario Portuguez, ou methodo de escrever cartas aconteceu em Lisboa, pelas Oficinas de Antonio Izidoro da Fonseca em 1745, e a última, segundo hipóteses historiográficas, 


\section{REVISTA DA ABRALIN}

ocorreu em 1823. Já a segunda edição, publicada em 1746, foi o livro de maior circulação do Brasil no século XVIII, conforme Araújo (1999). Fato que contribuiu para tal circulação nesse período foi o desenvolvimento tardio da prática epistolar em Portugal, pois as primeiras práticas missivas eram voltadas aos secretários, visto que essas pessoas continham o status de letrados, o que representava bons exemplos de civilidade. Aqui nós trabalhamos com a quinta edição, publicada em 1786, em Lisboa, conforme Figura 1 abaixo:

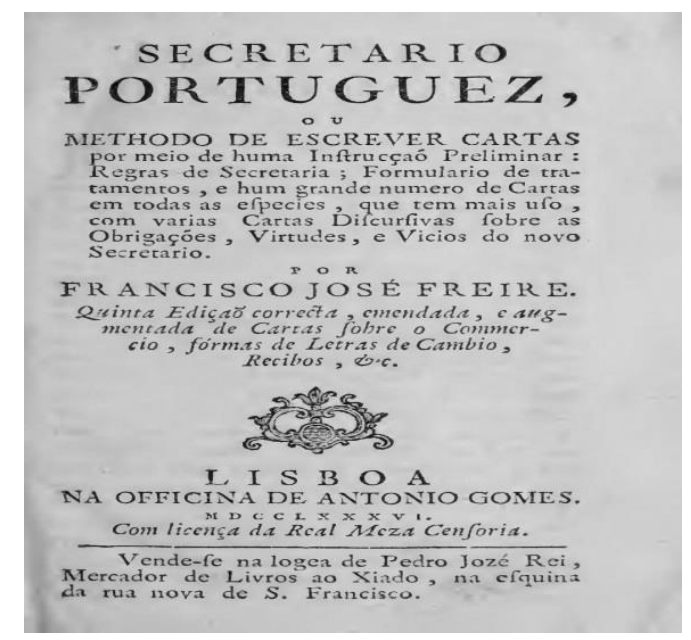

FIGURA 1 - Capa da quinta edição do Secretario Portuguez Fonte: Freire (1786)

Esse caráter de civilidade e instrução não foi inaugurado por Francisco José Freire, também conhecido como Candido Lusitano. É possível encontrar tal característica no primeiro manual de civilidade português de grande circulação, Corte na Aldeia (1619), de Francisco Rodrigues Lobo. Tal sucesso é explicado, segundo Chartier (2004), por dois elementos editoriais: a) ter sido publicado em latim, o que caracterizou uma unificação da civilidade na Europa Ocidental; b) tradução e adaptação às línguas genuínas com fins didáticos.

A exemplo disso, percebemos em Cândido Lusitano alguns mecanismos de leitura os quais Hansen (2008) compreende como instrumentos de leitura histórica discursiva. Portanto, dada a noção de autoridade do letrado é atrelada aos seus escritos uma grande significação, o que explica a circulação densa e duradoura dos Secretários e Manuais de Civilidade:

\footnotetext{
Naõ ha cousa commum como o escrever Cartas: e com tudo naõ he cousa commum o sabellas compor. [...] Para isto valem-se de preceitos, e de exemplos, os quaes, por serem muitos, (pois são muitas as diversidades de Cartas) mais servem a alguns para lhes confundir, que para lhes illustrar o entendimento. (FREIRE, 1786, p. VII)
}

O Secretario Portuguez, ou methodo de escrever cartas, aqui analisado, é composto por três momentos: 


\section{REVISTA DA ABRALIN}

- Instrução Preliminar: nesse momento é colocada em questão a construção de um secretário de qualidade, o qual precisa corresponder aos bons modelos de cartas utilizadas para ilustrar inúmeras situacionalidades.

- Modelos de cartas: aqui há, segundo o editor, uma maior quantidade de cartas relacionadas ao comércio.

- Suplemento: por fim, há uma ampliação de temas relacionados ao comércio a partir de um Tratado sobre teoria/prática do comércio.

Nesse contexto, observa-se o principal endereçamento da obra, ou seja, a comunidade leitora à qual a escrita do Secretario estava atrelada, visto que no primeiro momento a obra é dirigida ao secretário, esperando deste que reproduza os bons costumes.

Houve hum subtil engenho, que disse que a Arte de escrever ensina hum maravilhoso segredo, o qual he, de pintar a palavra, fallar aos olhos, e dar côr, e alma aos pensamentos. Se isto convem a qualquer Escrito, quanto melhor convirá ás Cartas, por meio da quaes se explicaõ, e manifestaõ os conceitos dos ausentes? (FREIRE, 1786, p. XXVI)

Já os suplementos são propostos aos homens do comércio, apesar de tais não constituírem, na maioria das vezes, uma classe letrada. Essa relação da produção das missivas é sugerida por Barbosa (2011):

Por isso, o modelo pronto de várias cartas sobre os mais variados assuntos concernentes ao comércio. Tal fato se justifica porque o comerciante ou aquele que exerce estas funções não são exigidas posições que representem a posição de letrado, com capacidade de ornar as matérias a partir do engenho. (BARBOSA, 2011, p. 95)

Ademais, o Secretario Portuguez, ou methodo de escrever cartas arrola inúmeras tipologias de missivas, por meio da retórica, de cunho: i) judicial: desculpa, lamúria e defesa; ii) demonstrativa: felicitações, advertência, louvor, agradecimento, oferecimento; iii) deliberativa: condolências, indicação, boas festas, conforto, exortação e conselho.

Além das várias construções de cartas-modelo, o Secretario apresenta relações de situacionalidades, a depender das formas de representação da escrita, bem como do destinatário e emissor do texto.

\footnotetext{
Os modelos e as circunstâncias da escrita epistolar tradicional estão longe, portanto, de serem adequadas a pessoas comuns ou às práticas sociais mais corriqueiras, visto que supõem sempre um alto grau de formalidade. (BARBOSA, 2011, p. 97)
}

Entretanto, ao longo das décadas os manuais foram adquirindo características distintas, visto que é retirado deles, no século XIX, o proposto didático. Por conseguinte, os manuais começam a ser apropriados por um público-alvo heterogêneo e popularizado. 


\section{REVISTA DA ABRALIN}

Nesse sentido não podiam faltar modelos de cartas de galanteio, além de indicações em relação à erudição, sobre as perfeições do trabalho de um secretário na produção de tais cartas de amor. Mesmo o número de cartas de amor, ou com um caráter de galanteio, sendo bem reduzido no manual, o autor traz um destaque acerca da preocupação do secretário com a ars dictaminis, ou seja, uma prática de retórica antiga (medieval) de escrita de cartas.

\footnotetext{
O Secretario deve em mutas cousas ser geral, principalmente na invençaõ, a qual com elegante descobrimento de Figuras veste os conceitos despidos de todo o adorno Rhetorico. Por exemplo: Eu vos amo. A invençaõ faz-se por tres modos: ou eh facil, ou profunda, ou ornada. O primeiro modo deriva-se dos Lugares, que se chamaõ proximos: [...] os vossos predicados me estimulaõ a amar-vos. $\mathrm{O}$ segundo deriva-se das causas, assim proximas, como remotas: e sempre com magnificencia usa de hum pomposo ornato de palavras graves: como: Enriqueceo-vos o Cco com taõ raros dotes, que movem a todos, para vos amar, e mui particularmente a mim, que tendo mais distincto conhecimento delles, lhes faria huma notavel injuria se com a grandeza delles não igualasse a do meu affecto. Deste modo se ajuntaraõ as cousas, que geraõ o amor. A invençaõ ornada toda consiste nos elegantes ornatos, que a vestem v.g. ${ }^{2}$ Como os Vossos olhos vencem em luz as Estrellas, assim tambem saõ hum vivo argumento da vossa formosura, e do meu amor. (FREIRE, 1786, p. XXVI-XXVII - grifos do autor)
}

Nessa perspectiva, vale contextualizar as noções moralizantes e puritanistas que embasavam os valores éticos da sociedade oitocentista. Esse fato justifica a grande produção e circulação dos manuais epistolares com modelos de carta de amor, pois, devido às estigmatizações sociais, os/as jovens encontravam uma forma discreta de galanteio.

O Mensageiro dos Amantes: Carcaz de Fréchas Amatorias; Manual Epistolar Galante, por Damião Casamenteiro, pretende apresentar em suas páginas preceitos teóricos e exemplos práticos de galanteio na tentativa de alcançar um feliz casamento.

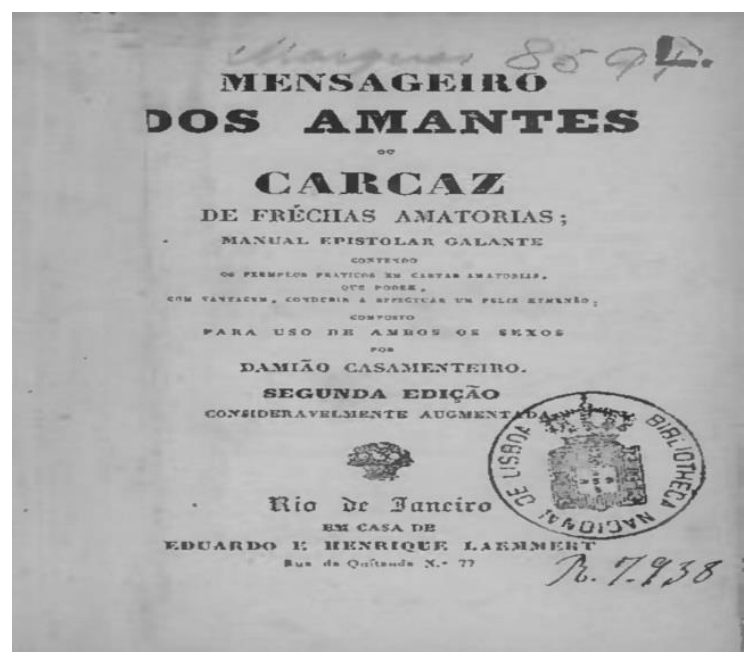

FIGURA 2 - Capa do Mensageiro dos Amantes: Carcaz de Fréchas Amatorias; Manual Epistolar Galante Fonte: Casamenteiro (18--)

\footnotetext{
2 Abreviatura do latim verbi gratia [por exemplo]. In: Dicionário Priberam da Língua Portuguesa, 2008-2020. Disponível em: https://dicionario.priberam.org/vg. Acessado em: 27/10/2020.
} 


\section{REVISTA DA ABRALIN}

O Mensageiro dos Amantes: Carcaz de Fréchas Amatorias; Manual Epistolar Galante, com sua $2^{\mathrm{a}}$ edição impressa no Rio de Janeiro, pela Casa de E. \& H. Laemmert em 18--, atribuído de forma jocosa a Damião Casamenteiro, é dividido em duas partes:

- Primeira parte: Prefácio, modelos de cartas de amor (105 cartas) e um Apêndice (advertência dos editores) sobre a publicação no prelo das cartas de Napoleão e Josephina. Não fica claro se a tipografia dispunha de uma versão ampliada para venda ou se as cartas traduzidas do original são as que estão publicadas no manual.

- Segunda parte: Cartas de Napoleão a Josephina, traduzidas do francês (21 cartas).

Por fim, apresentamos o Secretario Completo dos Amantes (19--), impresso em Lisboa pela Livraria Barateira, Imp. Lucas \& C. ${ }^{\text {a }}$, um manual que apresenta modelos de cartas de declaração de amor e respostas.

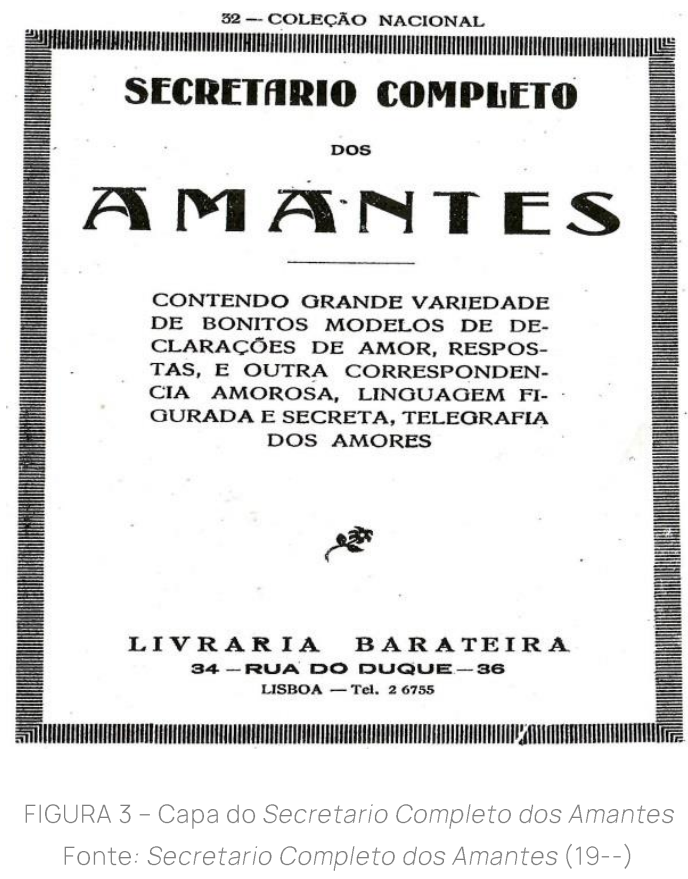

O Secretario Completo dos Amantes apresenta, além de cartas e respostas, um manual de linguagem figurada e telegrafia dos amores. Em relação a sua estrutura, esse Secretario é composto por três momentos:

- $\quad$ Linguagem das mãos: duas gravuras com as letras do alfabeto e os algarismos com a linguagem de sinais, seguido de uma explicação das gravuras, na qual destaca que para resolver os impasses que os namorados têm em trocar correspondências, através das 


\section{REVISTA DA ABRALIN}

gravuras autoexplicativas, será possível auxiliar os enamorados por meio da "telegraphia amorosa, o que sem duvida será novidade para muitos dos nossos leitores" (Secretario Completo dos Amantes, 19--, s/p).

- Introdução: representação do amor e conselhos para os leitores sobre a arte de conquistar a mulher, esclarecimentos acerca do amor, da mulher, do namoro, do casamento, além de uma apresentação sobre o perfil do matrimônio a partir da idade.

- Modelos de cartas: a primeira parte é dedicada à apresentação de cartas de declaração de amor. Destacamos que todos os modelos (16 cartas) são de enunciadores homens para enunciatárias mulheres; na segunda parte, dedicada às respostas às declarações de amor (22 cartas), temos a presença significativa de respostas das mulheres (16 modelos) e a resposta de homens às cartas que tiveram como enunciadoras as jovens enamoradas (6 cartas). Outra questão curiosa é que as cartas de declaração de amor (todas escritas por homens) são assinadas por seus enunciadores, enquanto que nas cartas de respostas (escritas em sua maioria por mulheres) apenas 12 delas são assinadas por mulheres (as demais apresentam a primeira letra do nome).

Percebemos que, diferentemente do Secretario Portuguez, que era uma obra dirigida, principalmente, ao secretário, no Secretario Completo dos Amantes, a comunidade leitora e público-alvo eram os jovens que estavam em fase de galanteio, em busca de pretendentes para um possível matrimônio.

\section{Das cartas de amor: composição e análise}

José Francisco Freire, em o Secretario Portuguez, estabelece uma regra geral para produção das cartas, exceto quando se tratar de cartas narrativas ou descritivas. Para o autor, o secretário deve considerar quatro ações obrigatórias: a) narrar um fato; b) rogar por um agradecimento ou agradecer por algo; c) oferecer préstimo ao receptor da carta; d) felicitar o enunciatário da carta.

Todas as Cartas (reservando as de narraçaõ, e descripçaõ) se dividem em quatro periodos. No primeiro se narra o facto; no segundo se roga a que se agradeça, ou respectivamente se dão os agradecimentos; no terceiro se offerece o prestimo; e no quarto se desejaõ felicidades. (FREIRE, 1786, p. VIII)

É importante observamos que, por mais que se proponha um formulário ou um estilo da arte de escrever cartas (CASTILLO GÓMEZ, 2002), construindo assim uma proposta de cânone epistolar, por meio de fórmulas e expressões consagradas pela epistolografia portuguesa, não se garante uma 


\section{REVISTA DA ABRALIN}

rigidez no ato de escrever, uma vez que, dependendo da natureza da carta e de seu enunciatário, tais fórmulas se moldam à finalidade da missiva.

Nesse sentido, tomamos como ponto de partida a definição da composição de carta de Freire (1786) para analisar se o gênero segue uma estrutura rígida da estrutura dos períodos (aqui considerados como ação). O recorte seguiu o que buscamos com a TD a partir dos estudos diacrônicos dos gêneros escritos. Vale destacar que nossa análise se assenta na proposta que trata o "gênero em seu percurso histórico de produção e circulação" concebendo-o "como tradição discursiva, pois esse conceito possibilita a apreensão do objeto de estudo em sua historicidade" (ZAVAM, 2009, p. 226).

A análise das 14 cartas, então, consistiu em estabelecermos uma ordem temporal de produção do impresso (1786, 18--, 19--) a partir do que o primeiro manual caracteriza como regra de escrita epistolar. Dessa forma, as regras de Freire (1786) serviram de ponto de partida para observamos se a reelaboração das cartas ao longo dos três séculos mantém estruturas fixas ou mutáveis. A numeração presente na análise segue a ordem da narratividade das cartas de amor. Assim, serão evidentes os possíveis deslocamentos das ações, uma vez que não há uma ordem canônica que obrigatoriamente deve ser seguida na produção das missivas. Vale destacar que, para seguirmos as regras de produção das missivas (FREIRE, 1786), foi necessário compreender a proposta teórico-metodológica para análise diacrônica e co(n)textual de gêneros ${ }^{3}$ (ZAVAM, 2009).

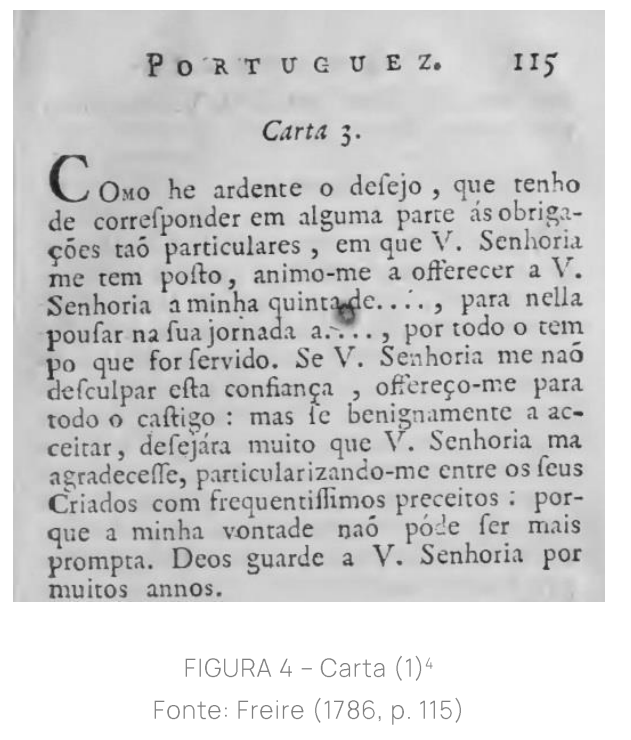

\footnotetext{
${ }^{3}$ Não replicaremos aqui a proposta teórico-metodológica, dada a natureza desta publicação, uma vez que deixaria o trabalho muito extenso. Por conseguinte, destacamos que analisar as cartas pelas regras de Freire (1786) só foi possível por meio da compreensão das seguintes categorias: ambiência, interlocutores, finalidade, conteúdo, norma e forma (ZAVAM, 2009).

${ }^{4}$ A fim de não causar confusão entre os números nas imagens das cartas e os números nas legendas da figura, optamos por seguir uma ordem numérica nas legendas, independentemente dos números que porventura apareçam nas imagens.
} 


\section{REVISTA DA ABRALIN}

Podemos perceber que em C1 (Figura 4) as quatro ações, ou os quatro períodos, encontram-se na composição da carta de amor, porém não seguem exatamente a ordem do que foi proposto por Freire (1786):

1) Narrar um fato

Período/Ação

3) Oferecer préstimo ao receptor da carta

2) Rogar por um agradecimento ou agradecer por algo

4) Felicitar o enunciatário da carta
Trecho da carta

Como he ardente o desejo, que tenho de corresponder em alguma parte ás obrigações taõ particulares, em que V. Senhoria me tem posto,

animo-me a offerecer a V. Senhoria a minha quinta de ...., para nella pousar na sua jornada a....., por todo o tempo que for servido. Se V. Senhoria me naõ desculpar esta confiança, offereço-me para todo o castigo:

mas se benignamente a acceitar, desejaria muito que V. Senhoria ma agradecesse, particularizando-me entre os seus Criados com frequentissimos preceitos: porque a minha vontade naõ póde ser mais prompta.

Deos guarde a V. Senhoria por muitos annos.

QUADRO 1 - Carta 1

Fonte: os autores

\section{Carta 6.}

A Nimo-me a offerecer a V. Excellencia effas..... : porque V. Excellencia pela fua benignidade permitte aos feus amigos o obrarem femelhantes acçóes. Bem defejára eu que follem muitá no número, e raras na bondade; porém a Eftaçaó o difpoz de outro modo, talvez para que eu moftraffe mais a grandeza do meu affecto, que do meu animo: motivo porque me animei, como tambem pela confideraçaó de que $\mathrm{V}$. Excellencia, quando fe ferve de acceitar as minhas galantarias, as recebe como fincéro final da minha amizade, e fervidaó, a favor das quaes peço a V. Exixellencia as fuas ordens. Deos guarde a V. Excellencia por muitos annos.

Em C2 (Figura 5) encontramos novamente as quatro ações na composição da carta, sem seguir a mesma ordem de $\mathrm{C} 1$ :

Período/Ação

3) Oferecer préstimo ao receptor da carta

1) Narrar um fato

2) Rogar por um agradecimento ou agradecer por algo

4) Felicitar o enunciatário da carta
Trecho da carta

Animo-me a offerecer a V. Excellencia essas....

porque V. Excellencia pela sua benignidade permitte aos seus amigos o obrarem semelhantes ações. Bem desejára eu que fossem muitas no número, e raras na bondade; porém a Estaçaõ o dispoz de outro modo, talvez para que eu mostrasse mais grandeza do meu affecto, que do me meu animo:

motivo porque me animei, como tambem pela consideraçaõ de que V. Excellencia, quando se serve de acceitar as minhas galantarias, as recebe como sincéro final da minha amizade, e servidaõ, a favor das quaes peço a V. Excellencia as suas ordens.

Deos guarde a V. Excellencia por muitos annos. 


\section{REVISTA DA ABRALIN}

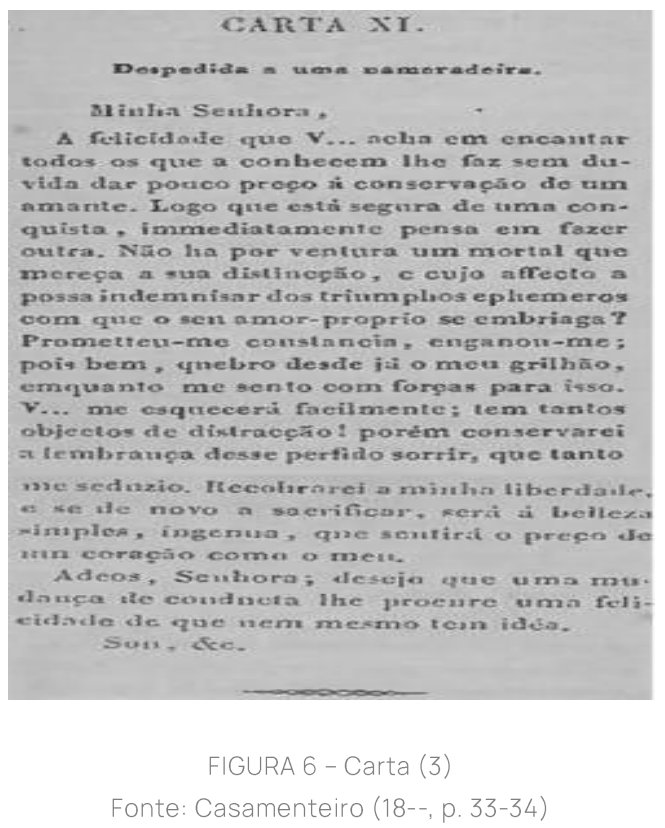

Em C3 (Figura 6) identificamos três das quatro ações e acrescentamos uma nova ação na composição da carta. Para mantermos a ordem da identificação das ações, conforme as transcrições, seguiremos nos quadros seguintes a alternativa de apresentar a ação de composição e marcar como "Não identificado":

\author{
Período/Ação \\ 1) Narrar um fato
}

2) Rogar por um agradecimento ou
agradecer por algo
3) Oferecer préstimo ao receptor da
carta
4) Felicitar o enunciatário da carta
*Encerrar o relacionamento

*Encerrar o relacionamento

\section{Trecho da carta}

A felicidade que V... acha em encantar todos os que a conhece lhe faz sem duvida dar pouco preço á conservação de um amante. Logo que está segura de uma conquista, immediatamente pensa em fazer outra. Não ha por ventura um mortal que mereça a sua distincção, e cujo affeto a possa indemnisar dos triunphos ephemeros com que o seu amor-proprio se embriaga? Prometteu-me constancia, enganou-me

Não foi identificado

Não foi identificado

desejo que uma mudança de conducta lhe procure uma felicidade de que nem mesmo tem idéa.

quebro desde já o meu grilhão, emquanto me sento com forças para isso. V... me esquecerá facilmente; tem tantos objectos de distração! porém conservarei a lembrança desse perfido sorrir, que tanto me seduzio. Recobrarei a minha liberdade, e se de novo a sacrificar, será á belleza simples, ingenua, que sentirá o preço de um coração como o meu.

\section{QUADRO 3 - Carta 3}

Fonte: os autores

\footnotetext{
${ }^{5}$ Será possível ainda em algumas cartas identificarmos novas ações, considerando a categoria de finalidade (ZAVAM, 2009). Para tanto, acrescentaremos mais uma linha no quadro que será identificada por meio de “*”, seguido do nome atribuído à finalidade.
} 


\section{REVISTA DA ABRALIN}

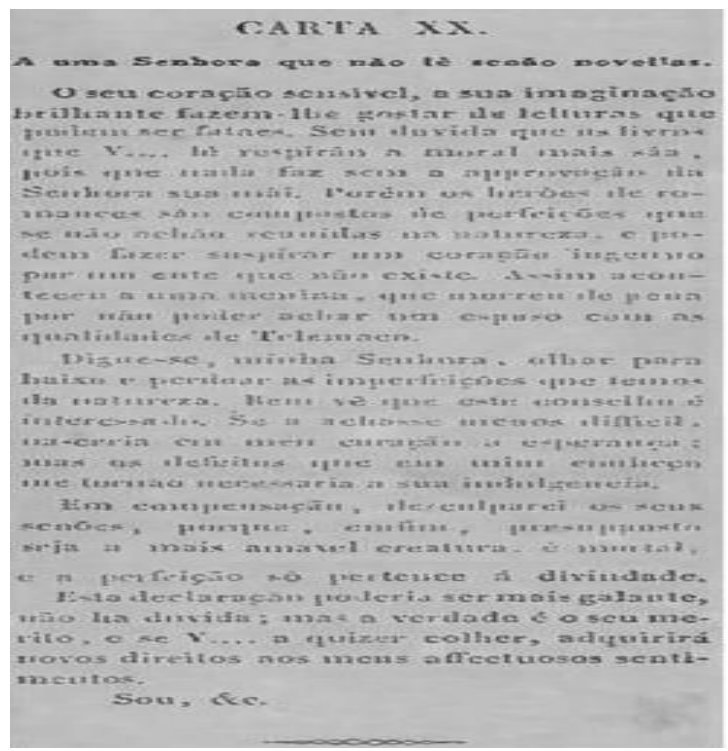

FIGURA 6 - Carta (4)

Fonte: Casamenteiro (18--. p. 52-54)

Em C4 (Figura 6), entre as quatro ações apontadas, só foi possível identificar a ação de "Narrar um fato". Além disso, identificamos uma nova ação na composição da carta:

Período/Ação

1) Narrar um fato

2) Rogar por um agradecimento ou agradecer por algo

3) Oferecer préstimo ao receptor da carta

4) Felicitar o enunciatário da carta *Aconselhar
Trecho da carta

O seu coração sensivel, a sua imaginação brilhante fazem-lhe gostar de leituras que podem ser fataes. Sem duvida que os livros que V... lê respirão a moral mais sãa, pois que nada faz sem a approvação da Senhora sua mãi.

Assim aconteceu a uma menina, que morreu de pena por não poder achar um esposo com as qualidades de Telemaco

Não foi identificado

Não foi identificado

Não foi identificado

Digne-se, minha Senhora, olhar para baixo e perdoar as imperfeições que temos da natureza. Bem vê que este conselho é interessado.

\section{QUADRO 4 - Carta 4}

Fonte: os autores 


\section{REVISTA DA ABRALIN}

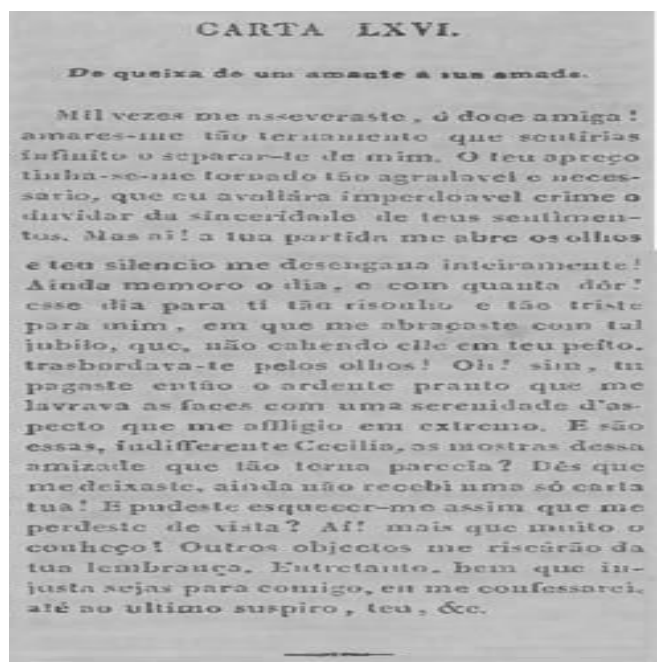

FIGURA 7 - Carta (5)

Fonte: Casamenteiro (18--, p. 170-171)

Em C5 (Figura 7) só encontramos, das quatro ações propostas por Freire (1786), a ação de "Narrar um fato". Acrescentamos uma outra ação na composição da carta:

1) Período/Ação

1) Narrar um fato

2) Rogar por um agradecimento ou agradecer por algo

3) Oferecer préstimo ao receptor da carta

4) Felicitar o enunciatário da carta

* Declarar amor
Trecho da carta

Mil vezes me asseverastes, ó doce amiga! amares-me tão ternamente que sentirias infinito o separar-te de mim. O teu apreço tinha-se-me tornado tão agradavel e necessario, que eu avaliára imperdoavel crime o duvidar da sinceridade de teus sentimentos. Mas ai! A tua partida me abre os olhos e teu silencio me desengana inteiramente!

Ainda memoro o dia, e com quanta dôr! esse dia para ti tão risonho e tão triste para mim, em que me abraçaste com tal jubilo, que, não cabendo elle em teu peito. transbordava-te pelos olhos! Oh! sim, tu pagaste então o ardente pranto que me lavrava as faces com uma serenidade d'aspecto que me affligio em extremo. E são essas, indifferente Cecilia, as mostras dessa amizade que tão terna parecia? Dés que me deixaste, ainda não recebi uma só carta tua! E pudeste esquecer-me assim que me perdeste de vista?

Não foi identificado

Não foi identificado

Não foi identificado

Entretanto. bem que injusta sejas para comigo, eu me confessarei, até ao ultimo suspiro, teu, \&c.

QUADRO 5 - Carta 5

Fonte: os autores 


\section{REVISTA DA ABRALIN}

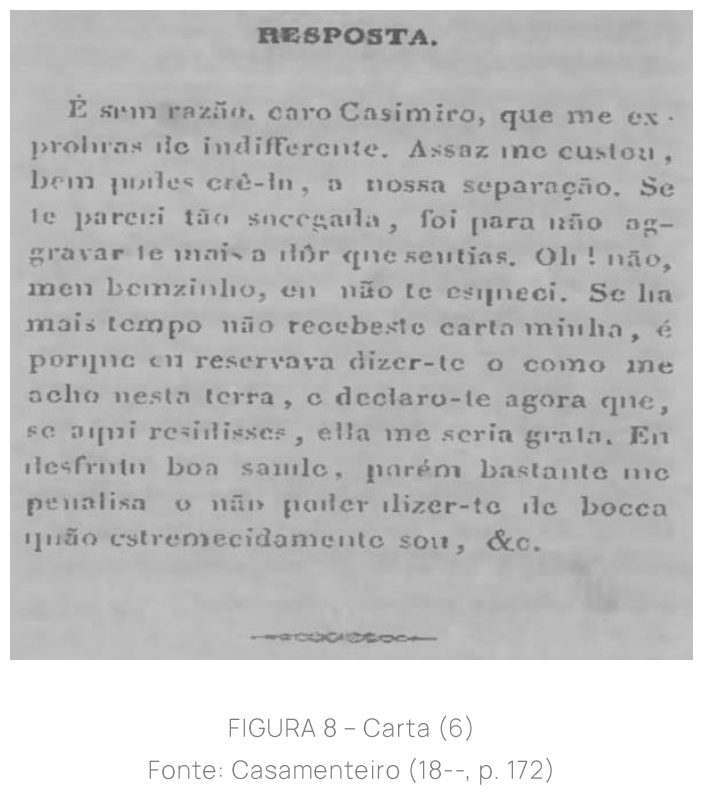

Em C6 (Figura 8), uma carta de resposta, só identificamos uma ação na composição da carta:

1) Narrar um fato

Período/Ação

2) Rogar por um agradecimento ou agradecer por algo

3) Oferecer préstimo ao receptor da carta

4) Felicitar o enunciatário da carta
Trecho da carta

Assaz me custou, bem podes crê-la, a nossa separação. Se te pareci tão socegada, foi para não agravar te mais a dôr que sentias! Oh! não, meu bemzinho, eu não te esqueci. Se ha mais tempo não recebeste carta minha, é porque eu reservava dizer-te o como me acho nesta terra

Eu desfruto boa saude, porém bastante me penalisa o não poder dizer-te de bocca quão estremecidamente sou, \&c.

Não foi identificado

Não foi identificado

Não foi identificado

\section{QUADRO 6 - Carta 6}

Fonte: os autores

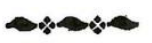

Ex. ${ }^{\text {as }}$ Sr.

Foi tremulo e vacillante que cheguei á resolação de lhe offerecer esta carta, porque jogava n'esta. a alegria de toda a minha vida e felicidade futura. alegria de toda a minha vida e felicidade futura.
0 assentimento de V. Ex." ao gosto do meu rogo, foi como a luz do sol brilhante que aquece os pobres desherdados!

E eu seria, sim, um triste desherdado, se a sua in. differença respondesse á minha supplica, se V. Ex. não aceitasse 'esta missiva.

Resta-me agradecer, senhora, a esperança que faz nascer no meu coração apaixonado, de que ainda pos. so ser feliz, ao lado da mulher que mais amo n'este so ser feliz, ao lado da mulher que mais amo n'esto
mundo, do anjo da guarda do meu futuro ditoso.

De V. Ex. a, admirador sincero, Fernando.

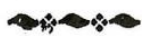




\section{REVISTA DA ABRALIN}

Em C7 (Figura 9), das quatro ações, encontramos apenas duas na composição da carta:

Período/Ação

Perío

3) Oferecer préstimo ao receptor da carta

4) Felicitar o enunciatário da carta

2) Rogar por um agradecimento ou agradecer por algo
Trecho da carta

Foi tremulo e vacillante que cheguei á resolução de lhe offerecer esta carta, porque n'esta a alegria de toda a minha vida e felicidade futura

$\mathrm{O}$ assentimento de V. Ex. ${ }^{\mathrm{a}}$ ao gosto do meu rogo, foi como a luz do sol brilhante que aquece os pobres desherdados!

Não foi identificado

Não foi identificado

Resta-me agradecer, senhora, a esperança que faz nascer no meu coração apaixonado, de que ainda posso ser feliz, ao lado da mulher que mais amo n'este mundo, do anjo da guarda do meu futuro ditoso.

\section{QUADRO 7 - Carta \\ Fonte: os autores}

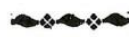

$$
\text { Ex. }^{\mathrm{ma}_{2}} \mathrm{Sr} \text { : }^{\prime}
$$

Baseado na muita sympathia que me inspirou, eu venho hoje confessarlhe que a amo loucamente, que venho hoje confosar the que tenha a adoro enthusiasticamente e rogar he que tenha alguma consideração de dando-the o refrigerio d'uma palavra, o lenitivo d'um olhar caritativo.

Sou sincero, creia-o.

Amo-a muito; muitissimo, e alguma coisa altamen.

te valiosa me falta. Que algo se passa. Sim. E' Q seu mor de amor de que eu prociso. Nená $\mathrm{V}$. grande Ex. em quem penso sempre e com quem son as noites e por quem passo longas vigilias? V. Ex. lavrará a minha sentença de vida ou de
morte, sentença que eu espero contricto e resignado.

De V. Ex.", com profundo respeito, Vasco.

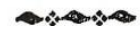

FIGURA 10 - Carta (8)

Fonte: Secretario Completo dos Amantes (19--, p. 13)

Em C8 (Figura 10) conseguimos identificar apenas uma das quatro ações na composição da carta:

\author{
Período/Ação \\ 1) Narrar um fato \\ 2) Rogar por um agradecimento ou \\ agradecer por algo \\ 3) Oferecer préstimo ao receptor da \\ carta \\ 4) Felicitar o enunciatário da carta
}

Não foi identificado

Trecho da carta

rogar-lhe que tenha alguma consideração de quem muito tem sofrido, dando-lhe o refrigerio d'uma palavra, o lenitivo d'um olhar caritativo.

Não foi identificado

Não foi identificado 


\section{REVISTA DA ABRALIN}

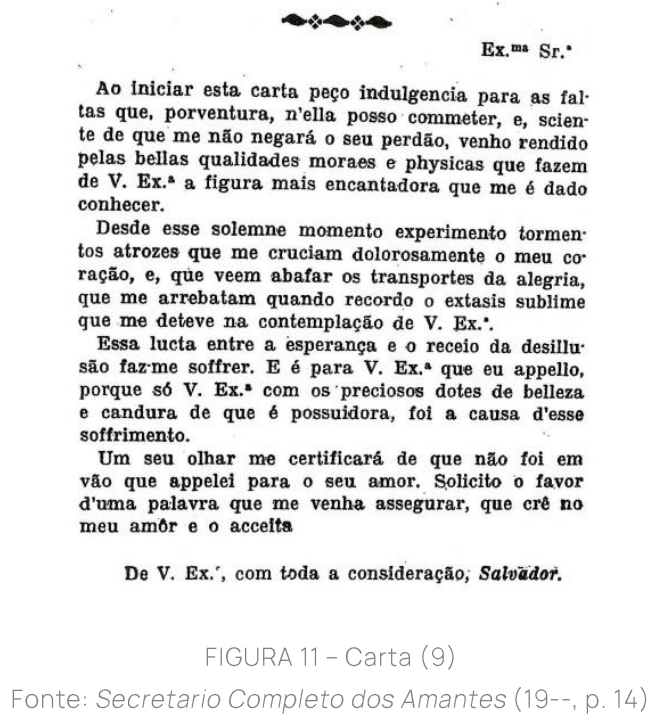

Em C9 (Figura 11) identificamos duas das quatro ações na composição da carta. Acrescentamos uma nova ação a partir da categoria de finalidade:

Período/Ação

4) Felicitar o enunciatário da carta

1) Narrar um fato

2) Rogar por um agradecimento ou agradecer por algo

3) Oferecer préstimo ao receptor da carta

*Pedir resposta
Trecho da carta

venho rendido pelas bellas qualidades moraes e physicas que fazem de V. Ex. ${ }^{a}$ a figura mais encantadora que me é dado conhecer.

Desde esse solemne momento experimento tormentos atrozes que me cruciam dolorosamente o meu coração, e, que veem abafar os transportes da alegria, que me arrebatam quando recordo o extasis sublime que me deteve na contemplação de V. Ex. $^{\mathrm{a}}$

Essa lucta entre a esperança e o receio da desillusão faz-me soffrer.

Não foi identificado

Não foi identificado

E é para V. Ex. ${ }^{a}$ que eu appello, porque só V. Ex. ${ }^{a}$ com os preciosos dotes de belleza e candura de que é possuidora, foi a causa d'esse soffrimento.

Um seu olhar me certificará de que não foi em vão que appelei para o seu amor. Solicito o favor d'uma palavra que me venha assegurar, que crê no meu amor e o acceita.

\section{QUADRO 9 - Carta 9}

Fonte: os autores 


\section{REVISTA DA ABRALIN}

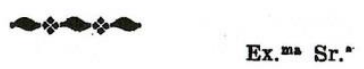

\footnotetext{
Meu coração está preso dos seus maravilhosos en.
cantos: segue-a a minha imaginação por toda a cantos : seguea a parte.

A ignorancia que se affigura V. Ex..$^{-}$ter do impe rio dos seus encantos fal-a ainda mais seductora, e, para que eu considere uma creatura completa, falta the apenas um coração terno-estou convencido de que o possue.

que o possue.

Como eu seria feliz se alcançasse fazer penetrar
de V. Ex." uma parcella do amor que me anima!

Via-a ha dias, minha senhora, e a sua elegancia,

seu porte distincto sem affectação fizeram de mim um louco de amor por V. Ex.s.

Verar-me ante a sua seductora ima. Venho, pois, py perrão para a amar e uma espe gem, a pedirlhe per.

rança do seu amor.

Aguardando anciosamente uma resposta, sou

De V. Ex. ${ }^{*}$, cr. ${ }^{\circ}$ att. $^{\circ}$ ven. ${ }^{\circ}$ Octaviano.

FIGURA 12 - Carta (10)

Fonte: Secretario Completo dos Amantes (19--, p. 18)
}

Em C10 (Figura 12) identificamos três das quatro ações na composição da carta:

Período/Ação

4) Felicitar o enunciatário da carta

1) Narrar um fato

3) Oferecer préstimo ao receptor da carta

2) Rogar por um agradecimento ou agradecer por algo

\section{Trecho da carta}

Meu coração está preso dos seus maravilhosos encantos: segue-a a minha imaginação por toda parte.

Via-a ha dias, minha senhora, e a sua elegancia, o seu porte distincto sem affectação fizeram de mim um louco de amor por V. Ex. ${ }^{\mathrm{a}}$.

Venho, pois, prostrar-me ante a sua seductora imagem, a pedir-lhe permissão para a amar e uma esperança do seu amor.

Não foi identificado

\section{QUADRO 10 - Carta 10 \\ Fonte: os autores}

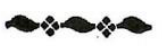

Ex. mo Sr.

E' inutil përsistir no seu intento, porque o facto de não responder á sua primeira carta equivale a uma recusa formal.

Fol talvez peor para V. Ex." obrigar-me a esta franqueza; mas... assim o quiz...

Não posso acceder ao seu pedido nem me sinto in. clinada a amal-o.

Perdóme, mas não o julgo susceptivel de fazer a' minha felicidade, porque não o amo.

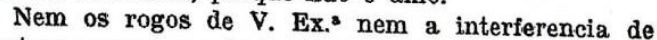
outras pessoas me farão demover do seu proposito.

Desculpe e creia-me muito respeitadora

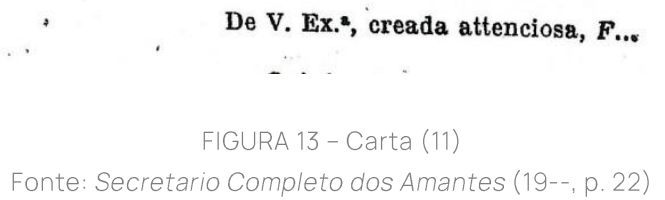

Em C11 (Figura 13) identificamos apenas a ação de "narrar um fato" na composição da carta. Acrescentamos uma nova ação: 


\section{REVISTA DA ABRALIN}

Período/Ação

1) Narrar um fato

2) Rogar por um agradecimento ou agradecer por algo

3) Oferecer préstimo ao receptor da carta

4) Felicitar o enunciatário da carta

*Pedir desculpas
Trecho da carta

É inutil persistir no seu intento, porque o facto de não responder á sua priemira carta equivale a uma recusa formal.

Foi talvez peor para V. Ex. ${ }^{a}$ obrigar-me a esta franqueza; mas... assim o quiz...

Não foi identificado

Não foi identificado

Não foi identificado

Desculpe e creia-me muito respeitadora

\section{QUADRO 11 - Carta 11}

Fonte: os autores

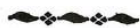

Sé o que lêmos n'uma folha de papel de carta bas. duvida conhecermos e acreditarmos sem sombra de vacillar um momento sequer. Mas não, que, quando nos

timentos que animam as pessoasamos sobre os sen grande razão temos para pôr em duvida o que nós escrevemos.

Não posso, nem devo affirmar que me é grato o amor que me confessa um homem que não conheço nem tâo pouco posso decidirme a amalo tambem. Isso seria uma loucura, uma leviandade sem cla sificaçẵo.

Pr. a minha franqueza, mas eu com prehendo que isó devo, e posso amar um homem de tidade e rectidão de caracter me não offereça duvida. Eis o motivo de eu não corresponder ao amor que me confessa.

Greia que não é outro o motivo, senão o receio de um desengano no futuro.

Perdoe-me e creia-me

Sinceramente attenciosa, Rosalina.

FIGURA 14 - Carta (12)

Fonte: Secretario Completo dos Amantes (19--, p. 23)

Em C12 (Figura 14) nenhuma das quatro ações foi identificada na composição da carta. Acrescentamos duas novas ações:

\footnotetext{
1) Narrar um fato

2) Rogar por um agradecimento ou

agradecer por algo

3) Oferecer préstimo ao receptor da carta

4) Felicitar o enunciatário da carta

*Descrever uma situação hipotética
}

Período/Ação

*Pedir desculpas
Não foi identificado

Trecho da carta

Não foi identificado

Não foi identificado

Não foi identificado

Se o que lêmos n'uma folha de papel de carta bastasse a conhecermos e acreditarmos sem sombra de duvida o que lá se escreve, amal-o-ia eu, senhor, sem vacillar um momento sequer.

Perdôe-me e creia-me 


\section{REVISTA DA ABRALIN}

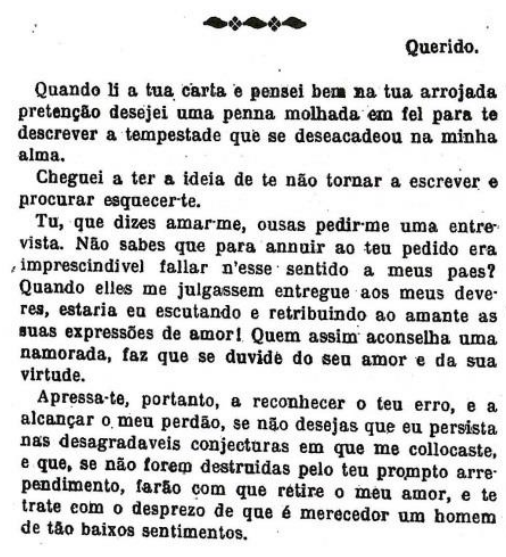

Com consideração, Virginia.

FIGURA 15 - Carta (13)

Fonte: Secretario Completo dos Amantes (19--, p. 28)

Em C13 (Figura 15) apenas a ação de "narrar um fato" foi identificada na composição da carta. Acrescentamos uma nova ação:

1) Período/Ação

2) Rogar por um agradecimento ou agradecer por algo

3) Oferecer préstimo ao receptor da carta

4) Felicitar o enunciatário da carta

*Pedir reconhecimento
Trecho da carta

Quando li a tua carta e pensei bem na tua arrojada pretensão desejei uma penna molhada em fel para te descrever a tempestade que se desencadeou na minha alma. Cheguei a ter a ideia de te não tornar a escrever e procurar esquecer-te.

Não foi identificado

Não foi identificado

Não foi identificado

Apressa-te, portanto, a reconhecer o teu erro, e a alcançar o meu perdão, se não desejas que eu persista nas desagradaveis conjecturas em que me collocaste, e que, se não forem destruidas pelo prompto arrependimento, farão com que retire o meu amor, e te trate com desprezo de que é merecedor um homem de tão baixos sentimentos.

\section{QUADRO 13 - Carta 13 \\ Fonte: os autores}

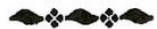

Minha Noemia

Queres que eu te diga o que eu li no teu rosto? Pareceste-me expansiva de contentamento.

Li as lagrimas intimas de uma alma que sabe que é adorada.

Resplandecia d'esses olhos, unicos em formosura e expressão, o intimo ardor em que se ha de queimar o coração que ouvir as palpitações do teu. Mal te fitei nos olhos temeroso de ser surprehendido.

Eu não tenho nem quero amigo intimo de quem confie este segredo.

Queria que toda a gente soubesse que tè amo, e ao mesmo tempo guarda como avarento este thesouro. Manda-me as flores promettidas, e um beijo na rosa unica. "Uma só!”

Teu adorador, Christiano. 


\section{REVISTA DA ABRALIN}

Em C14 (Figura 16) identificamos apenas duas ações na composição da carta:

\author{
1) Narrar um fato \\ Período/Ação \\ 2) Rogar por um agradecimento ou \\ agradecer por algo \\ 3) Oferecer préstimo ao receptor da \\ carta \\ 4) Felicitar o enunciatário da carta
}

\author{
Trecho da carta \\ Li as lagrimas intimas de uma alma que sabe que é adorada. \\ Resplandecia d'esses olhos, unicos em formosura e expressão, o intimo ardor em que \\ se ha de queimar o coração que ouvir as palpitações do teu. Mal te fitei nos olhos temer- \\ osos de ser surprehendido. \\ Não foi identificado \\ Não foi identificado \\ Manda-me as flôres promettidas, e um beijo na rosa única "Uma só!"
}

QUADRO 14 - Carta 14

Fonte: os autores

Após a análise da C14, apresentamos a hipótese de que a última ação (Felicitar o enunciatário da carta) se deu por uma prática comum da comunidade leitora jovem do Brasil oitocentos: a circulação e a leitura do Diccionario da Linguagem das Flores (1868). Essa obra servia como um manual de códigos de galanteio, por meio de uma linguagem secreta estabelecida pelos tipos de flores - "cada flor nos traz com um prazer uma nova expressão; temos procurado fixar algumas d'estas expressões, buscando na natureza de cada planta uma relação com nossas affeições moraes" (DICCIONARIO DA LINGUAGEM DAS FLORES, 1868, p. 8) -, suas características e a posição em que se apresenta:

\footnotetext{
Para fazer uso da linguagem das flores poucas regras bastam. A primeira consiste em saber que uma flor apresentada direita exprime um pensamento, e que basta invertê-la para que represente o contrario; assim um botão de rosa de musgo com seus espinhos e folhas que dizer: eu espero, mas receio; dando-se o mesmo botão voltado significa: não há que temer nem esperar. [...] Algumas modificações feitas na flor que se offerece lhe alteram a significação. Tomemos o botão que nos serviu de exemplo desguarnecido de seus espinhos, e elle nos dirá: ha tudo a esperar; e desguarnecido de folhas e não de espinhos, significa: ha tudo a temer. (DICCIONARIO DA LINGUAGEM DAS FLORES, 1868, p. 4 - grifos dos editores).
}

Nesse sentido, no trecho em que o jovem autor da carta se despede com um pedido: "Mandame as flôres promettidas, e um beijo na rosa única 'Uma só!", é possível perceber, tomando por base a linguagem secreta do Diccionario, que a estratégia adotada pelo enunciador ao usar plural para se referir a uma flor teria o propósito de destacar a intensidade da ação designada. De acordo com o Diccionario (1868), a rosa rainha significa beleza: "Ella é a imagem da mocidade, da innocencia, e do prazer; ella pertence a Venus, e rival da belleza possue a rosa como ella a graça, mais bella ainda que a propria belleza." (DICCIONARIO DA LINGUAGEM DAS FLORES, 1868, p. 172). A rosa única pode ser lida como a rosa rainha, por ser considerada a rainha das flores. Dessa forma, o enunciador estava elogiando a jovem amada, destacando a sua beleza.

Em relação aos dados obtidos por meio das análises das cartas de amor, a partir das regras de Freire (1786), pudemos identificar que, das 14 cartas, apenas as 2 do Secretario Portuguez apresentam as quatro ações em sua composição. Outro dado que nos chamou a atenção foi o fato de que nenhuma das cartas que compõem o nosso corpus seguem de forma rígida a ordem das ações apresentadas por Freire (1786): 1) narrar um fato; 2) rogar por um agradecimento ou agradecer por algo; 3 ) 


\section{REVISTA DA ABRALIN}

oferecer préstimo ao receptor da carta; 4) felicitar o enunciatário da carta. Há alternâncias na posição das ações: $\mathrm{C} 1$ - 1/3/2/4 e C2 - 3/1/2/4.

Das 14 cartas analisadas, 5 eram cartas de respostas, sendo apenas uma dessas escrita por um homem (C14). Identificamos que, nas cartas de respostas, 3 delas só apresentam a ação "1) Narrar um fato" (C6, C11, e C13), ou seja, 1 do século XIX e 2 do século XX, respectivamente. Observamos também que, em 3 cartas do século XIX, foi identificada só a ação de narrar (C4, C5, e C6 - apenas C6 era carta de resposta); no século XX, 2 cartas com a ação de narrar (C11 e C13).

Uma vez que a ação de narrar vem se destacando nas cartas, percebemos que, das 14 cartas, 12 apresentam essa característica. Em apenas C8 e C12, ambas do século XX, não identificamos a ação de narrar na composição. Importante destacar que 9 cartas são iniciadas por essa ação (C1, C3, C4, C5, C6, C7, C11, C13 e C14), mantendo-se uma certa equivalência, ou permanência, entre dois séculos: XIX e XX, cada um com 4 cartas. Apenas 1 carta do século XVIII (C1) apresenta essa característica de iniciar pela ação de narrar.

Em relação à ação "4) felicitar o enunciatário da carta", ela apareceu em 6 cartas no total. Dessas 6 cartas, 4 apresentam a ação de felicitar na posição final (C1, C2, C3 e C14), duas do século XVIII, uma do século XIX e outra do século XX, respectivamente, e 2 na posição inicial (C9 e C10), ambas do século XX.

Por fim, apenas a carta C12 (século XX) não apresentou nenhuma das quatro ações propostas na composição. Identificamos que havia uma descrição de uma situação hipotética e um pedido de desculpas ao longo da narratividade da missiva.

\section{Considerações finais}

A partir da análise das cartas de amor publicadas em manuais epistolares portugueses ao longo de três séculos (XVIII, XIX e XX), pudemos verificar o comportamento de mudanças e permanências em tradições discursivas através da análise diacrônica do genêro carta, em seu subgênero carta de amor.

Os manuais aqui apresentados foram publicados ao longo de três séculos, mas não podemos deixar de destacar que nosso intuito foi compreender o lugar das TDs nas cartas que circularam pela comunidade leitora brasileira do grande século XIX. A prática de traduções de obras de parte da Europa e as vendagens de livros e jornais portugueses, vindos de além-mar, caracterizam o interesse dos leitores brasileiros por tais obras, além de nos indicar a representação da sociedade oitocentista.

A permanência das cartas de amor e as inúmeras reedições dos manuais demonstram o interesse pela leitura e apropriação de textos dessa natureza. Outro fator importante de se destacar nessas considerações é que a abordagem analítica aqui utilizada foi motivada pela própria noção de regramento da arte de escrever cartas (FREIRE, 1786). Assim, reforçamos que o trabalho de análise diacrônica dos gêneros textuais não se restringe a um único modelo teórico-metodológico pré-estabelecido, bem como podemos recorrer a diferentes perspectivas de análise. 


\section{REVISTA DA ABRALIN}

Nesse sentido, percebemos que os modelos de missivas propostos no século XVIII, em relação às ações, não atendem a regras fixas ao longo dos séculos XIX e início do XX. Considerando que as TD se caracterizam por esse entre-lugar de mudança e permanência, o corpus aqui analisado pode confirmar que:

[...] as tradições discursivas dispõem de espaços para variação e para a mudança nos eixos sincrônico e diacrônico, sem perder o tronco comum que determina o seu pertencimento a uma dada linhagem de textos (GOMES, 2007, p. 196)

Dessa forma, vimos que os espaços de mudança se confirmaram nas ausências de ações na composição de 12 cartas de amor, além da criação de outras ações não previstas por Freire (1786) em 7 cartas, enquanto que o tronco comum, ou a permanência, ficou evidente na reelaboração das ações de narrar um fato e de felicitar o enunciatário da carta, aparecendo em 12 e 6 cartas, respectivamente, além do tema central das declarações de amor. Vale destacar que dos três manuais aqui analisados, apenas o de Freire (1786) tinha como principal finalidade comunicativa a arte de ensinar a escrever cartas, principalmente, para profissionais da pena. Os outros dois manuais tinham um caráter mais vulgar, destinado aos jovens que estavam em fase de galanteios.

\section{Agradecimentos}

Agradecemos ao Conselho Nacional de Desenvolvimento Científico e Tecnológico - CNPq pelo apoio financeiro que possibilitou a realização desse estudo através da Chamada MCTIC/CNPQ No 28/2018 - UNIVERSAL.

\section{REFERÊNCIAS}

ARAÚJO, J. S. Perfil do leitor colonial. Salvador: UFBA; Ilhéus: UESC, 1999. 502p.

BARBOSA, S. F. P. O conceito de literatura nos jornais do século XIX: um estudo dos jornais paraibanos. In: X Encontro Regional da ABRALIC, Rio de Janeiro. Anais... Rio de Janeiro: UERJ, 2005, p. 1-6.

BARBOSA, S. F. P. Códigos, regras e ornamentos nos secretários, manuais e métodos de escrever cartas: a tradição luso-brasileira. Veredas, Santiago de Compostela, n 15, p. 79-106, 2011.

BARBOSA, S. F. P. A escrita epistolar como prosa de ficção: as cartas do jornalista Miguel Lopes do Sacramento Gama. Revista Desenredo, Pelotas, v. 7, n. 2, p. 331-344, 2012.

CARVALHO, J. L. Q.; ZAVAM, A. Tradições Discursivas: conceitos e métodos para a análise diacrônica de gêneros. LaborHistórico, Rio de Janeiro, v. 4, n. 1, p. 41-54, jan./jun. 2018. DOI https://doi.org/10.24206/lh.v4i1.17489.

Acesso em: 15 outubro 2020 


\section{REVISTA DA ABRALIN}

CASAMENTEIRO, D. Mensageiro dos Amantes: Carcaz de Fréchas Amatorias; Manual Epistolar Galante. $2^{\mathrm{a}}$ ed. Rio de Janeiro: E. \& H. Laemmert, 18--. 300p.

CASTILLO GÓMEZ, A. Del tratado a la práctica. In: CASTILLO GÓMEZ, C.; SÁEZ, Antonio y. La correspondencia en la Historia. Modelos y práctica de la escritura epistolar: Actas del VI Congreso Internacional de Historia de la Cultura Escrita, vol. I. Valencia/Espanha: Calambur Editorial, 2002, p. 79-107.

CHARTIER, R. O mundo como representação. Estudos Avançados, São Paulo, v. 5, n. 11, p. 173- 191, 1991. DOI http://doi.org/10.1590/S0103-40141991000100010. Acesso em: 08 outubro 2020.

CHARTIER, R. A ordem dos livros. Brasília: Ed. Universidade de Brasília, 1998. 162p.

CHARTIER, R. Leituras e leitores na França do Antigo Regime. Trad. Álvaro Lorencine. São Paulo: Editora UNESP, 2004. 396p.

CHOPPIN, A. O historiador e o livro escolar. Revista História da Educação/ASPHE/UFPEL, Pelotas, v. 6, n 11, p. 5-24, 2002.

DICCIONARIO DA LINGUAGEM DAS FLORES. 3 ed. Lisboa: Thypographia Lusitana, 1868. 295p.

EL FAR, A. Páginas de Sensação: Literatura popular e pornográfica no Rio de Janeiro (1870-1924). São Paulo:

Companhia das Letras, 2004. 376p.

FREIRE, F. J. Secretario Portuguez, ou methodo de escrever cartas. 5 ed. Lisboa: Officina de Antonio Gomes, 1786. 500p.

GOMES, V. S. Traços de mudança e de permanência em editoriais de jornais pernambucanos: da forma ao sentido. $314 f$. Tese (Doutorado em Linguística) - Centro de Artes e Comunicação, Universidade Federal de Pernambuco, Recife, 2007.

HANSEN, J. A. Para ler as cartas do P.e Antônio Vieira. Teresa. Revista de Literatura Brasileira. DLCV, FFLCH, USP, São Paulo, n. ${ }^{\circ}$ 8/9, p. 264-299, 2008.

HOBSBAWM, E. J. A era dos impérios: 1875-1914. Trad. Sieni Maria Campos e Yolanda Steidel de Toledo. Rio de Janeiro: Paz e Terra, 1988. 588p.

KABATEK, J. Sobre a historicidade dos textos. Trad. José da Silva Simões. Linha d'água, n. 17, p. 159-170, 2005. DOI: http://doi.org/10.11606/issn.2236-4242.v0i17p157-170. Acessado em: 20 de setembro de 2020.

KABATEK, J. Tradição discursiva e gênero. In LOBO, T. et al (Org.). Rosae: linguística histórica, história das línguas e outras histórias [online]. Salvador: EDUFBA, p. 579-588, 2012. Disponível em:

http://books.scielo.org/id/67y3k/pdf/lobo-9788523212308-42.pdf. Acesso em: 20 de outubro 2020.

LAJOLO, M. Romance epistolar: o voyeurismo e a sedução dos leitores. Matraga, Rio de Janeiro, v. 1, n. 14, p. 61-75, 2002.

LEWIS. C. S. Alegoria do Amor: um estudo da tradição medieval. São Paulo: Realizações Editora, 2012. 400p.

RIAUDEL, M. Correspondência secreta. In: GALVÃO, W.; GOTLIB, N. B. (Orgs.). Prezado senhor, Prezada senhora Estudos sobre cartas. São Paulo: Companhia das Letras, 2000, p. 95-99.

ROMERO, S. História da literatura brasileira. BL Garnier, Rio de Janeiro, 1888. 720p.

ZAVAM, A. Por uma abordagem diacrônica dos gêneros do discurso à luz da concepção de tradição discursiva: um estudo com editoriais de jornais. 420f. Tese (Doutorado em Linguística) - Programa de Pós-Graduação em Linguística, Universidade Federal do Ceará, Fortaleza, 2009. 